ISSN 2073-4352

www.mdpi.com/journal/crystals

\title{
Communication
}

\section{Synthesis and Molecular Structure of 2-(Diphenylphosphano)phenyl Benzoate Borane Adduct}

\author{
Constantin Mamat ${ }^{1}$ and Martin Köckerling ${ }^{2, *}$ \\ 1 Institut für Radiopharmazie, Helmholtz-Zentrum Dresden-Rossendorf, Bautzner Landstraße 400, \\ D-01328 Dresden, Germany; E-Mail: c.mamat@hzdr.de \\ 2 Institut für Chemie, Universität Rostock, Anorganische Festkörperchemie, Albert-Einstein-Straße 3a, \\ D-18059 Rostock, Germany
}

* Author to whom correspondence should be addressed; E-Mail: martin.koeckerling @ uni-rostock.de; Tel.: +49-381-498-6390; Fax: +49-381-498-6382.

Academic Editor: Nikolaus Korber

Received: 5 November 2014 / Accepted: 12 December 2014 / Published: 29 December 2014

\begin{abstract}
The crystal and molecular structure of 2-(diphenylphosphano)phenyl benzoate borane adduct are reported. The title compound crystallizes from a petroleum ether/ethyl acetate mixture in the triclinic space group $\mathrm{P} \overline{1}$ with two molecules in the unit cell. The unit cell parameters are: $a=8.67(1) \AA, b=9.202(1) \AA, c=14.224(2) \AA ; \alpha=72.600(7)^{\circ}$, $\beta=73.577(7)^{\circ}, \gamma=84.349(7)^{\circ}$ and $V=1039.5(2) \AA^{3}$. Bond lengths and angles are typical for this phosphane borane adduct.
\end{abstract}

Keywords: building block; Lewis acid-base; Staudinger Ligation

\section{Introduction}

Staudinger Ligation reactions comprise a conjugation method for the introduction of various labels such as fluorescence dyes or radionuclides or for the connection of biologically active (macro-) molecules like peptides or carbohydrates under the formation of a carboxylic amide (peptide) bond between both ligation partners [1-3]. Functionalized phosphanes are widely applied as building blocks for the traceless variant of this ligation type. For this purpose, modified 2-(diphenylphosphano)phenyl derivatives are the basis which consist of a phosphanophenol unit where the $\mathrm{OH}$ group is located in ortho position to the central phosphorus atom of oxidation state + III. Prior to an application via the traceless 
Staudinger Ligation the $\mathrm{OH}$ group is esterified [4,5]. To modify the appropriate acid residue it is sometimes necessary to block the phosphorus atom, especially, when working with alkylating agents which can lead to phosphonium salts or under oxidative conditions. Borane $\left(\mathrm{BH}_{3}\right)$ is commonly used as protecting group and forms a stable air-resistant Lewis acid-base pair with the phosphane to prevent the aforementioned side reactions [6].

To introduce the borane protection group, two synthesis ways were pointed out recently. The first consists of the direct reaction of the borane protected phosphanophenol with acid chlorides under basic conditions and the second way involves the introduction of the $\mathrm{BH}_{3}$ group into the functionalized phosphane using $\mathrm{BH}_{3}$. THF [7]. Two crystal structures of closely related compounds resulting from such chemical reactions have been published before, see [4,5].

\section{Results and Discussion}

Recently, we have shown the formation of the title compound using the first synthesis way starting from acid chloride 1 and phosphanophenol 2 [4]. Here, we demonstrate the introduction of the $\mathrm{BH}_{3}$ group in the final step. For this purpose, starting compound $\mathbf{3}$ was dissolved in anhydrous THF and the $\mathrm{BH}_{3}$. THF complex solution was added at $-78{ }^{\circ} \mathrm{C}$. The resulting mixture was warmed to ambient temperature over $2 \mathrm{~h}$. After purification via column chromatography, compound 4 was isolated in $79 \%$ yield. Crystals of $\mathbf{4}$ were grown during the purification step from a saturated petroleum ether/ethyl acetate solution. The reaction procedure is shown in Scheme 1.

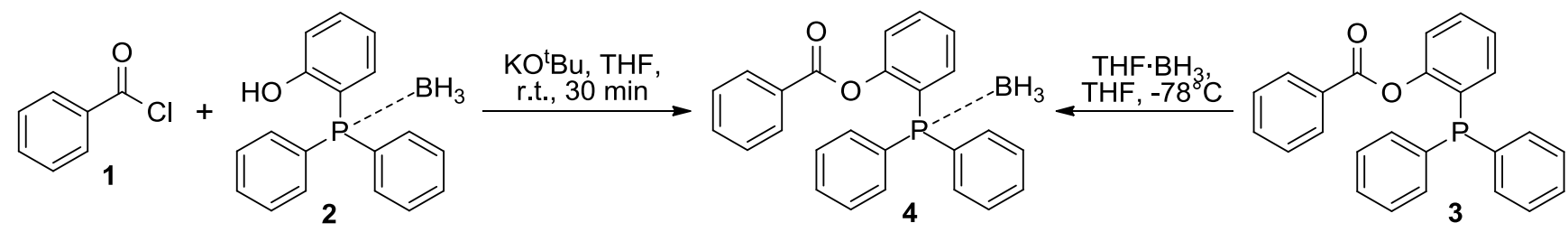

Scheme 1. Two synthesis ways for the preparation of phosphane borane adduct 4 .

The crystal and instrumental parameters used in the unit cell determination, the data collection, and structure refinement parameters are summarized in Table 1. The molecular structure of $\mathbf{4}$ is shown in Figure 1 with the used atom-labeling scheme. The displacement thermal ellipsoids are drawn at the 50\% probability level. Selected bond lengths comprising key features of 2-(diphenylphosphano)phenyl benzoate borane adduct 4 are given in Table 2 . The bond angles around the central $\mathrm{P}$ atom (P1) deviate from ideal tetrahedral and range from $105.23(5)^{\circ}$ for $\mathrm{C} 1-\mathrm{P} 1-\mathrm{C} 13$ to $116.97(5)^{\circ}$ for $\mathrm{B} 1-\mathrm{P} 1-\mathrm{C} 7$. The benzoate group is not arranged parallel to the P-bonded phenyl group. The torsion angle C13-C18-O1-C19 is $124.4(1)^{\circ}$. The packing of the molecules in the unit cell in a view along the crystallographic $b$ direction is shown in Figure 2. No mentionable interactions between the molecules exist besides those of the van-der-Waals type. 
Table 1. Crystal data and structure refinement for compound 4.

\begin{tabular}{|c|c|c|c|}
\hline \multicolumn{2}{|c|}{ Crystal data } & \multicolumn{2}{|c|}{ Refinement } \\
\hline Formula & $\mathrm{C}_{25} \mathrm{H}_{22} \mathrm{BO}_{2} \mathrm{P}$ & $\mathrm{F}(000)$ & 416 \\
\hline Formula weight & $396.20 \mathrm{~g} \cdot \mathrm{mol}^{-1}$ & Refinement method & Full-matrix least-squares on $F^{2}$ \\
\hline Temperature & $98 \mathrm{~K}$ & - & - \\
\hline Wavelength & $0.71073 \AA$ & Data/restraints/parameters & $5616 / 0 / 274$ \\
\hline Crystal system & Triclinic & - & - \\
\hline Space group & $\mathrm{P} \overline{1}$ & Goodness-of-fit on $F^{2}$ & 1.08 \\
\hline \multirow{6}{*}{$\begin{array}{c}\text { Unit cell } \\
\text { dimensions }\end{array}$} & $a=8.677(1) \AA$ & - & - \\
\hline & $b=9.202(1) \AA$ & Final $R$ indices & $R_{1}=0.0335$ \\
\hline & $c=14.224(2) \AA$ & & P $=00006$ \\
\hline & $\alpha=72.600(7)^{\circ}$ & {$[I>2 \sigma(I)]$} & $w R_{2}=0.0906$ \\
\hline & $\beta=73.577(7)^{\circ}$ & $R$ indices (all data) & \\
\hline & $\gamma=84.399(7)^{\circ}$ & $R$ indices (all data) & $R_{1}=0.0386$ \\
\hline Volume & $1039.5(2) \AA^{3}$ & - & $w R_{2}=0.0949$ \\
\hline Z & 2 & Largest diff. peak and hole & $0.51 /-0.28 \mathrm{e} \cdot \AA^{-3}$ \\
\hline Density (calcd.) & $1.266 \mathrm{~g} \cdot \mathrm{cm}^{-3}$ & - & - \\
\hline $\begin{array}{l}\text { Absorption } \\
\text { coefficient }\end{array}$ & $0.15 \mathrm{~mm}^{-1}$ & - & - \\
\hline Crystal size & $0.37 \times 0.35 \times 0.31 \mathrm{~mm}^{3}$ & - & - \\
\hline
\end{tabular}

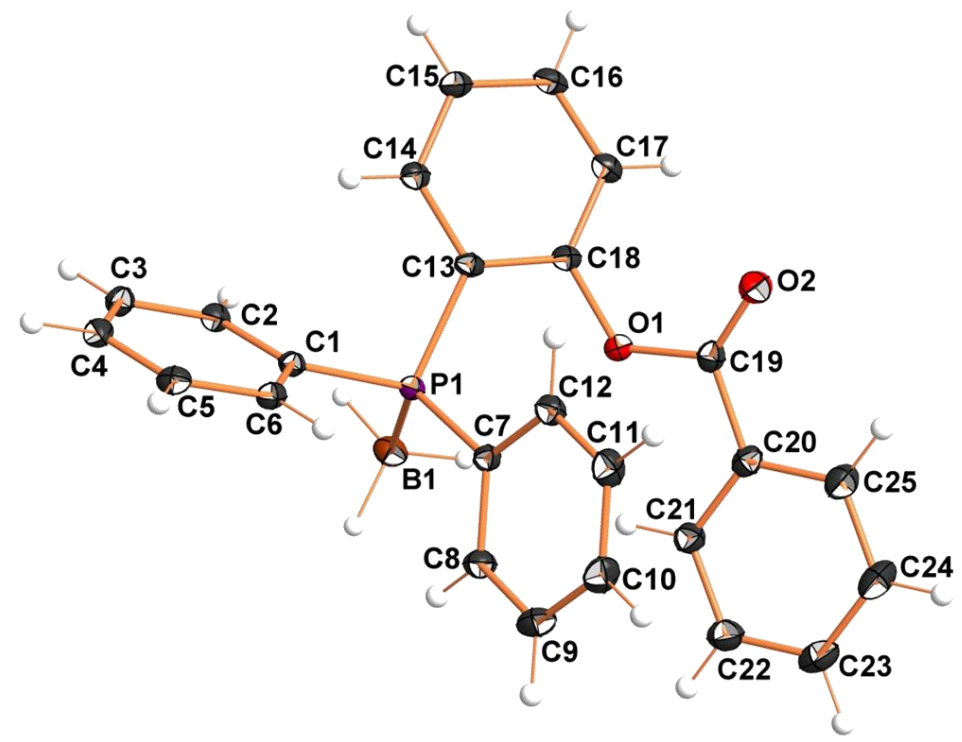

Figure 1. A view of the structure of the title molecules in crystals of $\mathbf{4}$ showing the atom labeling scheme. Displacement ellipsoids are drawn at the 50\% probability level.

Table 2. Selected atom distances $(\AA)$ in 4 .

\begin{tabular}{cccc}
\hline Atoms & Distance & Atoms & Distance \\
\hline P1-C1 & $1.815(1)$ & $\mathrm{C} 18-\mathrm{O} 1$ & $1.397(1)$ \\
$\mathrm{P} 1-\mathrm{C} 7$ & $1.808(1)$ & $\mathrm{O} 1-\mathrm{C} 19$ & $1.374(1)$ \\
$\mathrm{P} 1-\mathrm{C} 13$ & $1.822(1)$ & $\mathrm{C} 19-\mathrm{O} 2$ & $1.203(1)$ \\
$\mathrm{P} 1-\mathrm{B} 1$ & $1.932(1)$ & $\mathrm{C} 19-\mathrm{C} 20$ & $1.481(2)$ \\
\hline
\end{tabular}




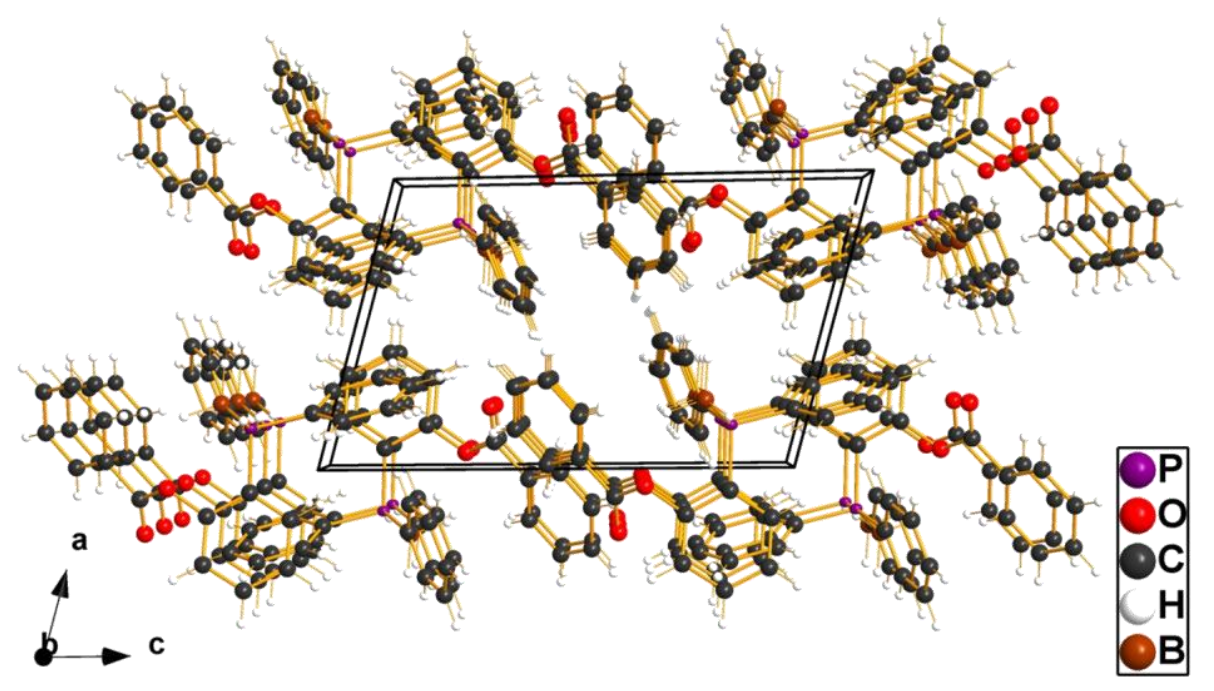

Figure 2. View of the packing of molecules in crystals of $\mathbf{4}$ along the crystallographic $b$ axis.

\section{Experimental Section}

\subsection{Synthesis of 2-(Diphenylphosphano)phenyl Benzoate Borane Adduct (4)}

2-(Diphenylphosphano)phenyl benzoate $(\mathbf{3}, 150 \mathrm{mg}, 0.39 \mathrm{mmol})$ [4] was dissolved in anhydrous THF ( $5 \mathrm{~mL}$, Sigma Aldrich, Schnelldorf, Germany) and cooled to $-78{ }^{\circ} \mathrm{C}$. Afterwards, $\mathrm{BH}_{3} \cdot \mathrm{THF}$ solution (1 M, $1.0 \mathrm{~mL}, 1.02 \mathrm{mmol}$, Sigma Aldrich, Schnelldorf, Germany) was added and the mixture was warmed to ambient temperature over a period of $2 \mathrm{~h}$. Next, the solvent was removed and purification was done via column chromatography (petroleum ether/ethyl acetate $=10: 1$ ) to yield $\mathbf{4}$ as colorless solid $(123 \mathrm{mg}, 79 \%)$. Data are in accordance with the previously published [4].

\subsection{Data Collection and Refinement}

Crystallographic data were collected with a Bruker-Nonius Apex-II CCD-diffractometer (Bruker-Nonius $\mathrm{GmbH}$, Karlsruhe, Germany), with monochromatic Mo-K $\alpha$ radiation $(\lambda=0.71073 \AA)$ and a CCD detector. Preliminary data of the unit cell dimensions was obtained from the reflection positions of 36 frames, measured in three different directions of the reciprocal space. After completion of the data measurements the reflex intensities were corrected for Lorentz, polarization and absorption effects. The structures were solved by direct methods using SHELXS-97 and refined against $F^{2}$ on all data by full-matrix least-squares methods using SHELXL-2014/1 [8,9]. All non-hydrogen atoms were refined anisotropically; all hydrogen atoms bonded to carbon atoms were placed on geometrically calculated positions and refined using riding models. The $\mathrm{H}$ atoms bonded to the $\mathrm{B} 1$ atom were refined isotropically. Crystallographic data has been deposited with the Cambridge Crystallographic Data Centre, CCDC-1029083. These data can be obtained free of charge via http://www.ccdc.cam.ac.uk/conts/retrieving.html.

\section{Conclusions}

The crystal and molecular structure of the title compound 2-(diphenylphosphano)phenyl benzoate borane adduct 4 is reported. These data represent well a crystallographically characterized example of a 
molecular compound with a Lewis acid-base adduct, which found various applications as building block for applications using the traceless Staudinger Ligation.

\section{Acknowledgement}

Alexander Villinger is gratefully acknowledged for maintaining the X-ray equipement.

\section{Author Contributions}

Constantin Mamat carried out all the conceptional as well as the synthetic and crystallization work. He wrote most of the manuscript. Martin Köckerling carried out the crystal structure determination.

\section{Conflicts of Interest}

The authors declare no conflict of interest.

\section{References}

1. Köhn, M.; Breinbauer, R. The Staudinger ligation-A gift to chemical biology. Angew. Chem. Int Ed. 2004, 43, 3106-3116.

2. Schilling, C.I.; Jung, N.; Biskup, M.; Schepers, U.; Bräse, S. Bioconjugation via azide-Staudinger ligation: An overview. Chem. Soc. Rev. 2011, 40, 4840-4871.

3. Van Berkel, S.S.; van Eldijk, M.B.; van Hest, J.C.M. Staudinger Ligation as a Method for Bioconjugation. Angew. Chem. Int. Ed. 2011, 50, 8806-8827.

4. Mamat, C.; Flemming, A.; Köckerling, M.; Steinbach, J.; Wuest, F.R. Synthesis of Benzoate-Functionalized Phosphanes as Novel Building Blocks for the Traceless Staudinger Ligation. Synthesis 2009, 3311-3321.

5. Mamat, C.; Franke, M.; Peppel, T.; Köckerling, M.; Steinbach, J. Synthesis, structure determination, and (radio-)fluorination of novel functionalized phosphanes suitable for the traceless Staudinger ligation. Tetrahedron 2011, 67, 4521-4529.

6. Staubitz, A.; Robertson, A.P.M.; Sloan, M.E.; Manners, I. Amine- and Phosphine-Borane Adducts: New Interest in Old Molecules. Chem. Rev. 2010, 110, 4023-4078.

7. Pretze, M.; Wuest, F.; Peppel, T.; Köckerling, M.; Mamat, C. The traceless Staudinger ligation with fluorine-18: A novel and versatile labeling technique for the synthesis of PET-radiotracers. Tetrahedron Lett. 2010, 51, 6410-6414.

8. Sheldrick, G.M. SHELXS-97 Programs for the Solution and Refinement of Crystal Structures; University of Göttingen: Göttingen, Germany, 1997.

9. Sheldrick, G.M. SHELXL2014/1 Programs for the Solution and Refinement of Crystal Structures; University of Göttingen: Göttingen, Germany, 2014.

(C) 2014 by the authors; licensee MDPI, Basel, Switzerland. This article is an open access article distributed under the terms and conditions of the Creative Commons Attribution license (http://creativecommons.org/licenses/by/4.0/). 